\title{
PENGARUH PENAMBAHAN BUAH NENAS DAN GARAM DENGAN KONSENTRASI YANG BERBEDA DALAM PEMBUATAN KECAP IKAN LAYANG DECAPTERUS SP TERHADAP TOTAL COLONI BAKTERI
}

\section{THE EFFECT OF ADDITION OF PINEAPPLE FRUIT AND SALT WITH DIFFERENT CONCENTRATION IN THE MAKING OF SMALL FISH DECAPTERUS SP TOTAL COLONI BACTERIA}

\author{
Nurfadilah $^{* 1}$ \\ ${ }^{1}$ Program Studi Program Studi Teknologi Pengolahan Hasil Laut, Politeknik Palu, Indonesia
}

\begin{abstract}
ABSTRAK
Ikan layang (Decapterus Sp.) merupakan salah satu hasil tangkapan sampingan yang masih kurang dimanfaatkan menjadi produk olahan yang memiliki nilai ekonomis, padahal potensinya cukup tinggi. Pengolahan ikan dengan proses fermentasi memiliki beberapa produk, salah satunya adalah pembuatan kecap ikan. Pemanfaatan buah nenas dalam fermentasi kecap ikan dapat mempercepat proses hidrolisis protein selama proses fermentasi dilakukan. Penelitian ini bertujuan untuk mengetahui perbandingan jumlah coloni bakteri yang terdapat pada kecap ikan layang Decapterus Sp dengan perlakuan buah nenas dan garam. Penelitian ini dilaksanakan di Laboratorium Terapan Teknologi Pengolahan Hasil Laut dan di Laboratorium Dasar Politeknik Palu. Metode yang digunakan dalam penelitian ini adalah metode analisis deskriptif. Identifikasi bakteri dan analisis usaha dilakukan secara kualitatif dan kuantitatif. Total mikroba terbanyak didapatkan pada kecap ikan yang tanpa menggunakan nenas $10 \%$ dan garam $7 \%$ yaitu $2,2 \times 10^{5}$ dan yang terendah terdapat pada kecap ikan yang menggunakan nenas $10 \%$ dan garam $7 \%$ yaitu $0,3 \times 10^{5}$ dan untuk analisis ekonomi layak untuk dipasarkan karena masih memiliki untung yaitu Rp. 1.900. kesimpulannya bahwa kecap ikan yang menggunakan nenas $10 \%$ dan garam 7\% layak untuk dikonsumsi maupun dipasarkan serta saran dilakukan pengujian lanjutan untuk masa simpan kecap ikan layang yang ditambahkan nenas 10\% dan garam $7 \%$.
\end{abstract}

Katakunci: Mutu Kimia, Nilai Ph, Silase Ikan, Penambahan Nenas dan Garam (NaCl)

\section{ABSTRACT}

Flying fish (Decapterus Sp.) Is one of the by-products that is still underutilized into processed products that have economic value, even though the potential is quite high. Processing of fish with a fermentation process has several products, one of which is the manufacture of fish sauce. While the addition of salt can maintain the shelf life of fish sauce This study aims to determine the comparison of the number of bacterial colony found in Decapterus Sp overcooked fish sauce treated with pineapple and salt. This research was conducted at the Applied Laboratory of Marine Products Processing Technology and at the Basic Polytechnic Laboratory of Palu. The method used in this research is descriptive analysis method. Bacterial identification and business analysis are carried out qualitatively and quantitatively. The highest number of microbes was obtained in fish sauce without using $10 \%$ pineapple and $7 \%$ salt which was $2.2 \times 105$ and the lowest was found in fish sauce using $10 \%$ pineapple and $7 \%$ salt which was $0.3 \times 105$ and for feasible economic analysis to be marketed because it still has a profit of Rp. 1,900. the conclusion is that fish sauce that uses $10 \%$ pineapple and $7 \%$ salt is suitable for consumption and marketing and suggestions for further testing for the shelf life of flying fish sauce are added 10\% pineapple and $7 \%$ salt.

Keywords: Chemical Quality, Ph Value, Fish Silage, Addition of Pineapple and Salt (Nacl) 


\section{Pendahuluan}

Ikan layang Decapterus Sp merupakan salah satu hasil tangkapan sampingan yang masih kurang dimanfaatkan menjadi produk olahan yang memiliki nilai ekonomis, padahal potensinya cukup tinggi. Di Sulawesi Tengah, peluang pengembangan industri cukup besar karena jenis-jenis ikan pelagis kecil (smallpelagic) dan ikan demersal dengan potensi sebesar 248.943 ton/tahun, sedangkan potensi umum daratan (PUD) mencapai 22.826,15 ton/tahun (Dinas Kelautan dan Perikanan Sulteng, 2010).

Pengolahan ikan dengan proses fermentasi memiliki beberapa produk, salah satunya adalah pembuatan kecap ikan. Menurut Ginting (2006), salah satu bentuk hasil olahan yang penting adalah kecap ikan. Pembuatan kecap ikan secara tradisional dilakukan dengan menambahkan garam dengan konsentrasi yang tinggi kemudian disimpan hingga proses fermentasi selesai. Menurut Prasetyo (2012), pembuatan kecap ikan yang dilakukan secara fermentasi dilakukan dengan penambahan garam dengan perbandingan berat ikan dan garam $3: 1$ atau $2: 1$ yang dicampur menjadi satu dan difermentasi selama 6 bulan pada suhu $300^{\circ} \mathrm{C}-350^{\circ} \mathrm{C}$.

Pembuatan kecap ikan secara tradisional memiliki beberapa kelebihan, yaitu nilai ekonomisnya tinggi dan proses pengolahannya mudah dan murah. Disamping itu, pembuatan kecap ikan secara sederhana juga memiliki kelemahan yaitu proses pembuatan yang cukup lama (Bima, 2013).

Kekurangan pembuatan kecap ikan secara tradisional menggunakan waktu fermentasi yang relatif lama yaitu $4-12$ bulan, lamanya proses fermentasi pembuatan kecap ikan yaitu untuk untuk memotong protein menjadi asam amino serta memberikan warna, rasa serta aroma yang baik pada kecap ikan. Proses fermentasi kecap ikan dapat dipercepat dengan proses hidrolisis protein ikan. Salah satunya yaitu dengan menambahkan bakteri asam laktat. Tujuannya adalah untuk mempercepat proses hidrolisis yang terjadi selama proses fermentasi (Bima, 2013).

Pemanfaatan buah nenas dalam fermentasi kecap ikan dapat mempercepat proses hidrolisis protein selama proses fermentasi dilakukan. Pemanfaatannya berprinsip pada kemampuan

\footnotetext{
${ }^{*)}$ Penulis Korespondensi.

E-mail: ilha.maruka.ias@gmail.com
}

dari ekstrak nenas untuk membuat suasana asam yang pas bagi pertumbuhan jamur kecap ikan. Sedangkan penambahan garam dapat mempertahankan masa simpan dari kecap ikan (Wulan, 2012).

Berdasarkan uraian diatas, maka penulis akan melakukan penelitian tentang Pengaruh Penambahan Buah Nenas dan Garam Dengan Konsentrasi yang Berbeda dalam Pembuatan Kecap Ikan Layang Decapterus Sp Terhadap Total Coloni Bakteri.

\section{Tujuan dan Manfaat}

Penelitian ini bertujuan untuk mengetahui perbandingan jumlah coloni bakteri yang terdapat pada kecap ikan layang Decapterus Sp dengan perlakuan buah nenas dan garam. Manfaat dari penelitian ini adalah untuk memberikan informasi kepada konsumen, produsen, dan distributor yang tertarik dengan bisnis pembuatan kecap ikan layang Decapterus Sp.

\section{Metode Penelitian}

\section{Waktu dan Tempat}

Penelitian ini dilaksanakan pada bulan Agustus 2017 di Laboratorium Terapan Teknologi Pengolahan Hasil Laut dan Laboratorium Dasar Politeknik Palu.

\begin{abstract}
Alat dan Bahan
Alat dan Bahan Pengolahan Kecap Ikan

Peralatan yang digunakan dalam pengolahan kecap ikan yaitu, kompor, talenan, pisau, wajan, saringan, blender, dan botol tempat penyimpanan. Bahan yang diperlukan dalam penelitian yaitu, ikan layang Decapterus Sp., buah nanas, garam, gula merah, daun salam, garam, kemiri, sereh, jintan.
\end{abstract}

\section{Alat dan Bahan Pengujian TPC}

Peralatan yang digunakan dalam pengujian TPC yaitu, glass wear, batang glass wear, batang gelas pengaduk, mikro buret skala 0,01 , cawan petri, cawan porselin, pipet $(1 \mathrm{ml}, 2 \mathrm{ml}, 5 \mathrm{ml}, 10$ $\mathrm{ml}$ ), incubator, luminary air flow, autoclave, tabung reaksi, erlenmeyer, timbangan analitik, oven, lampu spritus, pinset dan ember plastik.

\section{Parameter Pengujian}

Adapun parameter yang diuji yaitu pengujian TPC dan analisis usaha. 


\section{Proses Pembuatan Kecap Ikan}

Dalam pembuatan kecap ikan dilakukan sebanyak 2 perlakuan gunanya sebagai kontrol dalam pengujian Coloni bakteri. Pembuatan kecap ikan dilakukan dengan pertama menyediakan seluruh alat dan bahan seperti pisau, talenan, wajan, botol dan selang untuk wadah fermentasi, baskom dan kompor. Dan bahan-bahan seperti ikan layang Decapterus Lajang, buah nenas, gula merah, sereh, garam, air, dan daun salam. Pisahkan bahan untuk yang jadi perlakuan 1 dan perlakuan 2 .

Pembersihan terlebih dahulu ikan layang Decapterus Lajang dan rebus menggunakan air bersih sebanyak $1500 \mathrm{ml}$ masing-masing sebanyak 100 gr sampai mendidih (16 menit). Kemudian, Penirisan dan ambil air rebusan ikan tersebut kemudian campurkan dengan nenas dan semua bumbu-bumbu kecap ikan yang telah diseediakan untuk perlakuan 1 menggunakan garam $7 \%$ (3,5gr) dan nenas $10 \%$ (6,8gr). Sedangkan untuk perlakuan (kontrol) tanpa menggunakan garam dan nenas. Kemudian, dinginkan dan setelah didinginkan tiriskan dan pengisian dalam botol untuk dilakukan fermentasi selama \pm 7 hari. Untuk lebih jelas, disajikan dalam tabel 1 perlakuan pembuatan kecap ikan sebagai berikut.

Tabel 1. Perlakuan Pembuatan Kecap Ikan

\begin{tabular}{lll}
\hline Bahan & $\begin{array}{l}\text { Perlakuan } \\
\text { (Kontrol) }\end{array}$ & Perlakuan 2 \\
\hline $\begin{array}{l}\text { Ikan layang } \\
\text { (Decapterus }\end{array}$ & $100 \mathrm{gr}$ & $100 \mathrm{gr}$ \\
$\begin{array}{l}\text { Lajang) } \\
\text { Air }\end{array}$ & $1500 \mathrm{ml}$ & $1500 \mathrm{ml}$ \\
Nenas & $0 \mathrm{gr}$ & $6,8 \mathrm{gr}$ \\
Garam & $0 \mathrm{gr}$ & $3,5 \mathrm{gr}$ \\
Kemiri & $3 \mathrm{biji}$ & $3 \mathrm{biji}$ \\
Daun salam & 1 lembar & 1 lembar \\
Sereh & 1 batang & 1 batang \\
Jintan & 1 sendok & 1 sendok \\
& makan & makan \\
\hline
\end{tabular}

Sumber. Prasetyo, (2012).

\section{Proses Pengujian TPC}

Menurut standar SNI 01-1339, (2006), penimbangan contoh secara septic sebanyak $25 \mathrm{~g}$. Untuk contoh $25 \mathrm{~g}$ tambahkan $225 \mathrm{ml}$ larutan Butterfield's phosphate buffered, homogenkan selama 2 menit. Hommogenat ini merupakan larutan pengenceran $10^{-1}$. Dengan menggunakan pipet steril, ambil $1 \mathrm{ml}$ homogennat dan masukkan kedalam $10^{-2}$. Siapkan pengenceran selanjutnya $10^{-3}$ dengan mengambil pengenceran $10^{-2}$ kedalam $9 \mathrm{ml}$ larutan Butterfield's phosphate buffered. Pada setiap pengenceran dilakukan pengocokkan minimal 25 kali. Selanjutnya lakukan hal yang sama untuk pengenceran $10^{-4}$ dan $10^{-5}$. Pipet $1 \mathrm{ml}$ dari setiap pengenceran $10^{-1}$, $10^{-2}, 10^{-3}, 10^{-4}$ dan $10^{-5}$ memasukkan kedalam cawan petri steril. Lakukan secara duplo untuk setiap pengenceran, selanjutnya penambahan 12 $\mathrm{ml}-15 \mathrm{ml}$ PCA yang sudah didinginkan dalam waterbath hingga mencapai suhu $45^{\circ} \mathrm{C} \pm 1 \mathrm{ml}$ kedalam masing-masing cawan yang berisi contoh. Agar contoh dan media PCA tercampur sempurna lakukan pemutaran cawan kedepan, kebelakang, kekiri dan kekanan. Setelah media agar menjadi padat, untuk penentuan mikroorganisme aerob inkubasi cawan-cawan tersebut dalam posisi terbalik dalam incubator selama 48 jam \pm 2 jam pada $35^{\circ} \mathrm{C}$,selanjutnya setelah 48 jam. \pm 2 jam dilakukan perhitungan total plate count. Menurut SNI 01-2339, (2006) bahwa, cawan yang mengandung jumlah coloni 30-300 coloni dan bebas spreader yang dihitung. Perhitungannya sebagai berikut.

$$
\mathrm{n}=\frac{\sum \mathrm{C}}{[(1 \times \mathrm{n} 1)+(0,1 \times \mathrm{n} 2) \times(\mathrm{d})]}
$$

Keterangan:

$\mathrm{N} \quad=$ adalah jumlah coloni produk yang dinyatakan dalam $\mathrm{C} / \mathrm{ml}$ atau $\mathrm{C} / \mathrm{g}$.

$\sum \mathrm{C}=$ adalah jumlah coloni pada semua cawan yang terhitung.

$\mathrm{n}_{1} \quad=$ adalah jumlah cawan pada pengenceran pertama yang dihitung.

$\mathrm{n}_{2} \quad=$ adalah jumlah cawan pada pengenceran pertama yang dihitung.

$\mathrm{d} \quad=$ adalah pengenceran pertama yang dihitung.

Data hasil perhitungan coloni mikroba selanjutnya ditabulasikan. Hasil tabulasi selanjutnya dilakukan analisis deskriptif.

\section{Analisis Data}

Data yang diperoleh akan dianalisa secara deskriptif. Menurut Husaini (2008), deskriptif artinya melukiskan variabel demi variabel, satu demi satu. Dengan demikian metode deskriptif diinginkan untuk melukiskan secara sistematis fakta atau karakteristik populasi tertentu

\section{Hasil dan Pembahasan \\ Hasil Pengujian TPC Kecap Ikan}

Menurut Sunaewan (2012), analisis total mikroba menunjukkan mutu mikrobiologi suatu bahan pangan. Mutu mikrobiologi perlu diketahui untuk melihat tingkat cemaran mikroba pada 
produk olahan pangan tersebut sehingga dapat dikethui tingkat kemanannya untuk dikonsumsi selanjutnya.

Hasil uji total bakteri yang terdapat pada kecap ikan layang Decapterus Lajang yang menggunakan buah nenas $10 \%$ dan garam $7 \%$ dan tanpa menggunakan nenas $10 \%$ dan garam 7\% disajikan pada tabel 2 .

Tabel 2. Hasil uji total bakteri pada kecap ikan layang Decapterus Lajang yang menggunakan nenas $10 \%$ dan garam $7 \%$ serta yang tidak menggunakan nenas dan garam.

\begin{tabular}{lcl}
\hline \multicolumn{1}{c}{ Sampel Kecap } & \multicolumn{1}{c}{$\begin{array}{c}\text { ALT } \\
\text { (Rata-rata } \\
\text { koloni/gram) }\end{array}$} \\
\hline $\begin{array}{l}\text { Kontrol (tanpa) } \\
\text { dan garam }\end{array}$ & nenas & $2,2 \times 10^{5}$ \\
$\begin{array}{l}\text { Menggunakan } \\
\text { dan garam }\end{array}$ & nenas & $0,3 \times 10^{5}$ \\
\hline
\end{tabular}

Rata-rata total bakteri kecap ikan layang Decapterus Lajang dari 2 sampel adalah terdapat pada total bakteri kecap ikan layang Decapterus Lajang yang tanpa menggunakan buah nenas $10 \%$ dan garam $7 \%$, yaitu $2,2 \times 10^{5}$ Koloni $/ \mathrm{g}$ sedangkan nilai ambang batas maksimum berdasarkan SNI No. 01-3543-2009 maksimal total mikroba yaitu $1 \times 10^{5}$ ini artinya kecap ikan yang tanpa menggunakan buah nenas $10 \%$ dan garam $7 \%$ tidak sesuai dengan syarat mutu kecap ikan dan tidak layak untuk dikonsumsi.

Total bakteri terendah terdapat pada kecap ikan layang Decapterus Lajang yang menggunakan buah nenas $10 \%$ dan garam $7 \%$ yaitu $0,3 \times 10^{5}$. Dalam hal ini, dapat diketahui bahwa kecap ikan yang ditambahkan buah nenas $10 \%$ dan garam $7 \%$ sesuai dengan syarat mutu kecap ikan berdasarkan SNI No. 01-3543-2009 maksimal total mikroba yaitu $1 \times 10^{5}$ artinya, kecap ikan yang menggunakan buah nenas $10 \%$ dan garam $7 \%$ sesuai dengan syarat mutu kecap ikan dibawah $1 \times 10^{5}$, yaitu $0,3 \times 10^{5}$ artinya kecap ikan yang menggunakan buah nenas $10 \%$ dan garam 7\% masih layak untuk dikonsumsi.

Pembuatan kecap ikan menggunakan nenas dan garam lebih rendah total mikroba dikarenakan garam yang ditambahkan pada kecap ikan layang dapat menghambat pertumbuhan mikroba karena garam dapat mengikat air yang terkandung dalam kecap ikan serta cepat dalam proses fermentasinya yaitu selama \pm 7 hari yang disebabkan karena penambahan buah nenas yang memiliki kandungan enzim bromelin yang berguna untuk mempercepat waktu fermentasi.
Menurut Darkuni, (2012) bahwa penambahan garam pada pembuatan produk selain membari cita rasa, juga berfungsi sebagai pengawet. Adapun mekanisme garam sebagai pengawet adalah pertama garam bersifat higroskopis yaitu akan menyerap kandungan air pada bahan pangan, sehingga tidak dapat digunakan oleh mikroba untuk media pertumbuhannya, kedua garam bersifat osmotik yaitu menyerap air pada dinding sel bakteri sehingga terjadi plasmolisis (pemecahan dinding sel), ketiga garam merupakan Natrium Klorida $(\mathrm{NaCl})$ yaitu $(\mathrm{Na}+)+(\mathrm{Cl}-)$ dimana $\mathrm{Cl}$ - bersifat toksin bagi mikroba sehingga mikroba tidak dapat tumbuh.

Sedangkan fungsi enzim bromelin dalam pembuatan kecap ikan layang Decapterus Sp adalah untuk memotong waktu fermentasi dari pembuatan kecap ikan layang Decapterus Sp. Seperti yang dikemukakan oleh Akmlum, (2013), yaitu rekayasa penambahan enzim proteolitik sebelum fermentasi dapat mempersingkat waktu pembuatan kecap ikan. Dalam hal ini tidak diperlukan lagi waktu adaptasi mikroorganisme untuk menghasilkan enzim yang dapat menghidrolisis protein. Mahalnya harga enzim proteolitik yang murni menjadi kendala untuk menghasilkan kecap ikan yang cepat, mudah dan murah. Namun dengan memanfaatkan ekstrak buah nenas sudah dapat menggantikan peran enzim proteolitik yang murni tadi. Dalam buah nanas, khususnya nanas muda juga terdapat enzim proteolitik lain yaitu bromelin. Kemampuannya dalam menghidrolisis protein.

\section{Kesimpulan dan Saran}

\section{Kesimpulan}

Dari pembahasan diatas dapat disimpulkan bahwa kecap ikan yang dibuat dengan menggunakan buah nenas $10 \%$ dan garam $7 \%$ masih layak untuk dikonsumsi karena total mikrobanya sesuai dengan SNI No. 01-35431999 maksimal total mikroba yaitu di bawah $10^{5}$ dan sesuai menurut analisis ekonomi layak untuk dipasarkan karena dari tiap pembuatan kecap ikan $200 \mathrm{ml}$ memiliki keuntungan sebesar Rp. $1.900,00$. Serta kandungan diuretik dan kalium dalam buah nenas dapat membantu mengatasi asam urat serta peluang pasarnya luas dan mudah karena bisa melalui media sosial membuat bisnis kecap ikan bisa untuk dikembangkan. 


\section{Saran}

Saran untuk hasil penelitian ini adalah agar kita selalu menjaga sanitasi dan hygiene dalam pembuatan produk. perlu dilakukan pengujian lanjutan jika ada yang ingin membuat usaha rumah tangga yaitu dengan melakukan pengujian lanjutan total plate count kecap ikan selama masa simpan dan uji kandungan protein.

\section{Daftar Pustaka}

Bima. 2013. "Praktikum Pembuatan Kecap Ikan Dengan Penambahan Enzim Bromelin 5\% Dan Kadar Garam 20\%”. Akademi Perikanan Sidoarjo. Jawa Timur. (Skripsi).

Darkuni. 2012. "Laporan Mikrobiologi Umum: pengaruh Terhadap Pertumbuhan Mikroba". Universitas Haluoleo. http://faktor-faktorlingkungan.com.

Diakses pada 21 Agustus 2017.
Dinas Kelautan dan Perikanan Provinsi Sulteng. 2010. "Potensi Ikan Hasil Tangkapan Samping Sulawesi Tengah".

Sunarman. 2012. "Analisis Mikrobiologi pada Makanan Hasil Laut".

Prasetyo. 2012. "Pembuatan Kecap Ikan Secara Hidrolisis Enzimatis dari Sari Buah Nenas". Universitas Diponegoro : Semarang. Fakultas Perikanan dan Ilmu kelautan. Institut Pertanian Bogor. (Skripsi).

Wulan. 2010. "Studi Pembuatan Kecap Ikan dengan Penambahan Garam yang Berbeda". Universitas Diponegoro : Semarang. (Skripsi 